\title{
Upper Gastrointestinal Endoscopy - Our Findings, Our Experience in Lagoon Hospital, Lagos, Nigeria
}

\author{
Emmanuel Jeje ${ }^{1}$, Thomas Olajide $^{1^{\star}}$, Bashir Akande $^{2}$ \\ ${ }^{1}$ College of Medicine, University of Lagos, Department of Surgery, Lagos, Nigeria; ${ }^{2}$ Lagoon Hospital, Apapa, General \\ Surgery, Lagos, Nigeria
}

\begin{abstract}
Citation: Jeje E, Olajide T, Akande B. Upper Gastrointestinal Endoscopy - Our Findings, Our Experience in Lagoon Hospit, Lagos, Nigeria. Experience in Lagoon Hospital, Lagos, Nigeria. http://dx doi. Key words: Indications; Findings; $\mathrm{H}$ pylori; Upper gastrointestinal; Endoscopy.

"Correspondence: Dr. Thomas Olagboyega Olajide. College of Medicine, University of Lagos, Surgery College of Medicine, University of Lagos, Idi-Araba, Surulere, Lagos 101014, Nigeria. E-Mail: seyiolajide@gmail.com

Received: 05-Jan-2012; Revised: 07-Mar2013; Accepted: 13-Mar-2013; Online first: 17-Apr-2013

Copyright: (c) 2013 Jeje E. This is an openaccess article distributed under the terms of the Creative Commons Attribution License, which permits unrestricted use, distribution, and reproduction in any medium, provided the original author and source are credited.

Competing Interests: The authors have declared that no competing interests exist.
\end{abstract}

\begin{abstract}
Background: Upper gastrointestinal (UGI) endoscopy is a safe and sensitive investigation in the diagnosis of upper gastrointestinal disease. There are few reports on endoscopy in private institutions in Nigeria; therefore we decided to report our early experience in a private health facility in Lagos, Nigeria.

Aim: This study aims to document the indications and common findings in UGI endoscopy and evaluate the relationship between $\mathrm{H}$ pylori and endoscopic findings.

Methods: The indications for UGI endoscopy and findings detected over a 3-year period were analyzed.

Results: The commonest symptoms were epigastric pain, other upper abdominal pain, and dyspepsia while common signs were epigastric and right upper quadrant tenderness, and epigastric mass. Complete data was obtained in 172 patients of which 114 had abnormal findings. The commonest were duodenal ulcer, gastritis and duodenitis. Less common findings were gastric ulcer, gastric cancer and oesophageal cancer. There was no significant difference in the frequency of $\mathrm{H}$. pylori infection between those with normal and abnormal endoscopic findings.
\end{abstract}

Conclusion: The commonest indication for UGI endoscopy in Lagos, Nigeria is dyspepsia while the commonest endoscopic abnormalities are duodenal ulcer, gastritis and duodenitis.

\section{Introduction}

Upper gastrointestinal (UGI) endoscopy is the most sensitive investigation for diagnosing UGI disease [1]. Diagnostic endoscopy is a safe procedure, with less than $2 \%$ complication rate, usually minor [1]. Majority of patients referred for endoscopy have symptoms generally termed dyspepsia [2-4]. Dyspepsia refers to pain or discomfort centred in the upper abdomen.

The main purpose of the UGI endoscopy is identification of aetiology in order to commence appropriate treatment. A secondary reason is to exclude organic UGI disease [5]. Diseases commonly detected by UGI endoscopy are reflux oesophagitis (and its complications), oesophageal varices, oesophageal cancer, gastric ulcer, gastric cancer and duodenal ulcer [5].

Helicobacter pylori infection is the most important environmental factor in the development of chronic gastritis, peptic ulcer disease and gastric cancer [6-7]. It is therefore important to take biopsy for $\mathrm{H}$. pylori during endoscopy. In Nigeria, most of the reports have been from government teaching hospitals and only few have documented indications. Therefore, we decided to report our early experience over a three-year period in a 40-bed private health facility (Lagoon hospital) in Lagos, Nigeria.

The objectives of this prospective study are to document the indications and common findings in UGI endoscopy in our facility, evaluate the relationship between $\mathrm{H}$ pylori and endoscopic findings and to look out for other lessons learnt. 


\section{Patients and Methods}

This is a prospective study about our experience of upper gastrointestinal (UGI) endoscopy performed on one hundred and eighty four (184) consecutive patients seen at Lagoon Hospital, Apapa over a three-year period (December 1994 to December 1997). All adults and children referred or presenting to our hospital with persistent upper abdominal symptoms, clinical features of dyspepsia, peptic ulcer disease, upper gastrointestinal bleeding, gastric outlet obstruction, etc., were evaluated by the general surgeons and had UGI endoscopy performed on them. Also included were those who had had radiological investigations for the conditions just mentioned.

Informed consent was obtained from each patient after clinical evaluation and the hospital management approved the study. Oral and written instructions were given and each patient fasted for a minimum of six hours before the procedure. Endoscopies were performed weekly at the endoscopy unit of this private facility as day cases. Following administration of $0.02 \%$ lignocaine pharyngeal spray and administration of intravenous analgesia and sedative agents (pethidine, buscopan and midazolam) in those who had no contraindications to the use of these agents UGI was performed, using Olympus (GIF 30), forward viewing, flexible, fibre optic oesophagoduodenoscope, following established guidelines. The patients were closely monitored with pulse-oximeter during the procedure. Multiple biopsy samples from gastric antrum, gastric ulcers, gastric tumours and other suspicious lesions were taken for histology. Endoscopic diagnoses were based on widely accepted criteria.

Campylobacter-Like Organism (CLO) test for Helicobacter pylori was introduced in 1997, when it became available and all subsequent patients were tested. Patients were subsequently transferred to the recovery room, observed until stable and discharged home. They were counselled not to drive or operate machinery and avoid spicy or hot food for 24 hours. Follow up of the patients was done at the surgical outpatient department of the hospital.

The bio data of all patients, findings and follow up were input into pro forma. The data were analyzed using Statistical Package for Social Sciences, version19.0 (SPSS Inc. Chicago, Illinois). Continuous data are presented as Mean \pm SEM, while categorical data are presented as median. The data are also presented as tables and graphs. Statistical inference used student $t$ test and for discontinuous (categorical) variable chi square was used.

\section{Results}

A total of one hundred and eighty four patients had upper gastrointestinal endoscopy performed on them during the study period from December 1994 to December 1997. No significant complication was recorded. The procedure was not completed in one patient, in whom the duodenum was not entered, mainly because of poor patient cooperation. Twelve patients' $(7 \%)$ data were incomplete because they did not show up for follow up. There were more males $(101\{54.9 \%\})$ than females (83\{45.1\%\}) giving a male to female ratio of 1.2:1. The patients ranged in age from 10 to 83 years with mean of $42.2 \pm 1.1$ years. Figure 1 shows the age distribution of the patients.

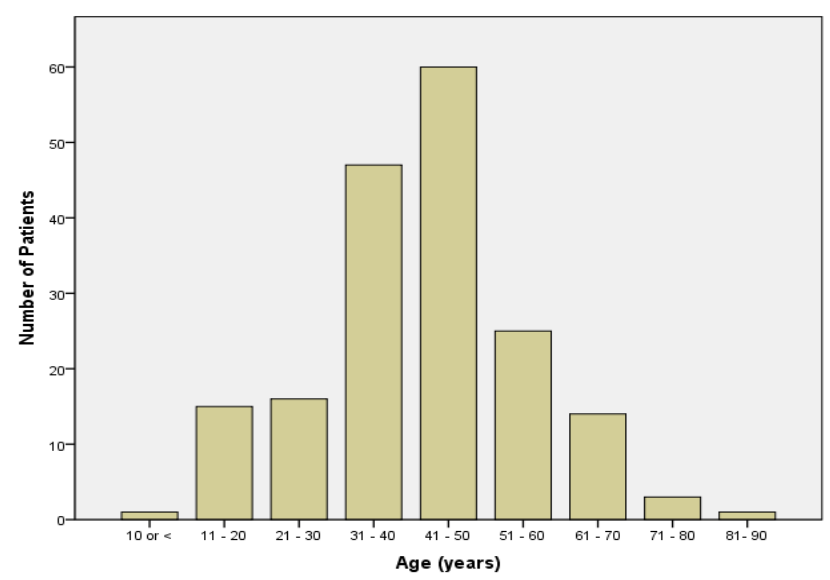

Figure 1: Age distribution.

Most patients were aged between 21 and 60 years, very few under 20 or above 70 years of age. One hundred and twenty three (67.6\%) of the patients were in the age group 21-50 years.

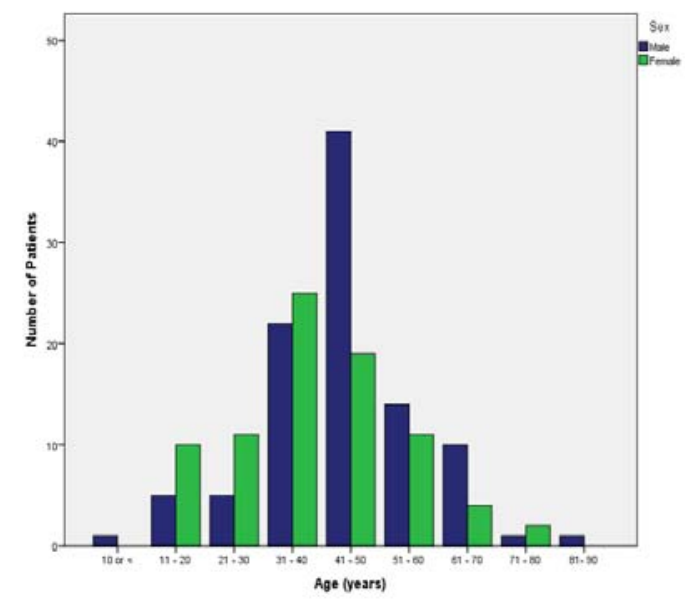

Figure 2: Age and sex distribution.

The most common presenting symptoms were epigastric pain (30.2\%), other upper abdominal pain, and dyspepsia or a combination of these symptoms (78.6\%). Thirty (17.4\%) of the patients had upper gastrointestinal bleeding (Table 1). 
Table 1: Presenting symptoms $(n=172)$.

\begin{tabular}{lcc}
\hline & Number & $\%$ \\
\hline Dyspepsia/Abdominal Pain & 136 & 78.6 \\
UGl Bleeding & 30 & 17.4 \\
Vomiting & 18 & 10.5 \\
Weight Loss & 15 & 8.7 \\
Nausea & 9 & 5.2 \\
Abdominal Swelling & 6 & 3.5 \\
\hline
\end{tabular}

Vomiting occurred in 18(10.5\%) and weight loss in $15(8.7 \%)$. The duration of symptoms was poorly documented, ranging from 3 days to 15 years. The common physical signs (Table 2) were epigastric tenderness (31.4\%), tenderness in the right upper quadrant (4.7\%), epigastric mass (4.1\%) and hepatosplenomegaly $(2.9 \%)$. Five patients $(2.9 \%)$ had a clinical diagnosis of gastric outlet obstruction. Only six patients (3.5\%) had had barium studies, previously. Four (66.7\%) were reported as abnormal of which $2(50 \%)$ were duodenal ulcer, one was duodenal cap deformity and the fourth one was reported as inconclusive.

Table 2: Clinical features $(n=172)$.

\begin{tabular}{lcc}
\hline & Number & $\%$ \\
\hline Epigastric Tenderness & 54 & 31.4 \\
Tender RUQ & 8 & 4.7 \\
Murphy's Sign & 2 & 1.2 \\
Tender RIF & 3 & 1.7 \\
Tender LIF & 1 & 0.6 \\
Tender LUQ & 2 & 1.2 \\
Epigastric Mass & 7 & 4.1 \\
RIF Mass & 1 & 0.6 \\
Hepatosplenomegaly & 5 & 2.9
\end{tabular}

RUQ, Right Upper Quadrant; RIF, Right Iliac Fossa; LIF, Left lliac Fossa; LUQ, Left lliac Fossa.

There were abnormal endoscopic findings in 114 of 172 patients (66.3\%). Of the abnormal findings, the commonest was duodenal ulcer active or chronic, in 35 patients (31\%)\}. Gastritis including erosions accounted for the next common lesion, noted in 32 patients $(28 \%)$. Duodenitis was found in 31 patients (27\%), gastric ulcer in $8(7.9 \%)$, however there was considerable overlap between the first three as gastritis was present in several patients with duodenal ulceration and duodenitis.

Table 3: Abnormal endoscopic findings $(n=172)$.

\begin{tabular}{lcc}
\hline & Number & $\%$ \\
\hline GER & 7 & 6 \\
Oesophagitis & 6 & 5.2 \\
Gastritis & 29 & 25.3 \\
Duodenitis & 31 & 27 \\
Gastric Ulcer & 9 & 7.9 \\
Duodenal Ulcer & 35 & 31 \\
Pyloric Stenosis & 3 & 2.5 \\
Oesophageal Cancer & 2 & 1.7 \\
Gastric Cancer & 7 & 5.7 \\
\hline
\end{tabular}

GER, Gastro-oesophageal reflux.

Oesophagitis was noted in $7 \%$, gastrooesophageal reflux in $6 \%$, oesophageal varices in $3.5 \%$, pyloric stenosis in $2.6 \%$, hiatus hernia in $0.9 \%$.
Gastric cancer was found in 7 patients (6\%) and oesophageal cancer in $2(2 \%)$. In the 10 patients who presented with upper gastrointestinal haemorrhage, gastric erosion (40\%) and oesophageal varices (40\%) were the commonest findings; bleeding duodenal ulcer and gastric ulcer were each responsible for $10 \%$ each. One patient with massive upper gastrointestinal bleeding from duodenal ulcer had to have an emergency under running of the bleeding vessel, truncal vagotomy and pyloroplasty.

Tables 4 and 5 show correlations between clinical presentations and endoscopy findings.

Twenty nine patients were tested for $\mathrm{H}$ pylori using the CLO test. Of the 13 patients with normal endoscopic findings $8(57 \%)$ tested positive for $\mathrm{H}$ pylori; sixteen patients had various abnormal endoscopic findings of gastritis, duodenal ulcer, gastric ulcer, gastric cancer and duodenitis out of which $10(62.5 \%)$ tested positive for $\mathrm{H}$. pylori. There was no significant statistical difference between the frequency of $\mathrm{H}$. pylori infection between those with endoscopic abnormality and those with normal findings ( $p$ value $=0.056)$.

\section{Discussion}

Upper gastrointestinal endoscopy was first introduced into English speaking West Africa including Nigeria almost half a century ago. It is thus important to continually evaluate the indications, endoscopic findings and the relevance of $\mathrm{H}$ pylori infection [8, 9]. This study was based at Lagoon Hospital, Apapa, a leading highbrow private facility in Lagos, Nigeria accessible mainly to the middle and upper socioeconomic group.

There were more males (54.9\%) than females (ratio 1.2:1) in this study similar to findings in majority of studies at other centres probably because UGI tract diseases are more prevalent in males [10-14]. Olokoba et al at llorin noticed a male:female ratio of 1.05 to 1 [10]. Agbakwuru et al at lle Ife also found more males (53.4\%) similar to what was noted by Malu et al, Danbauchi et al in Zaria, North West, Nigeria and Aduful et al in Accra, Ghana. However Nkrumah in Saudi Arabia and Khurram et al in Pakistan noticed more females in their studies. Probably, more females are being referred in the centres for endoscopy $[15,16]$. The age pattern is closely similar to those of other studies, with very few presenting before the age of 20 years, peaking in the fifth decade and a mean age of $42 \pm 1.1$ years probably because UGI tract diseases are prevalent in this population groups [11, 13-17]. The reason for the differences in the sex and age distribution is probably due to varying sample size, geographical locations and time periods the studies were carried out. 
Table 4: Correlation between symptoms and endoscopic findings.

\begin{tabular}{|c|c|c|c|c|c|c|c|c|c|}
\hline Symptom & $\begin{array}{c}\text { GERD } \\
(\%) \\
(p v)\end{array}$ & $\begin{array}{l}\text { Oesophagitis } \\
\begin{array}{c}\text { (\%) } \\
\text { (pv) }\end{array}\end{array}$ & $\begin{array}{c}\text { Gastritis } \\
\text { (\%) } \\
\text { (pv) }\end{array}$ & $\begin{array}{c}\text { Duodenitis } \\
\text { (\%) } \\
\text { (pv) }\end{array}$ & $\begin{array}{l}\text { Gastric } \\
\text { Ulcer } \\
(\%) \\
\text { (pv) }\end{array}$ & $\begin{array}{l}\text { Duodenal } \\
\text { Ulcer } \\
(\%) \\
(p v)\end{array}$ & $\begin{array}{c}\text { Pyloric } \\
\text { Stenosis } \\
\text { (\%) } \\
\text { (pv) }\end{array}$ & $\begin{array}{c}\text { Oesophageal } \\
\text { Cancer } \\
(\%) \\
(p v)\end{array}$ & $\begin{array}{c}\text { Gastric } \\
\text { Cancer } \\
(\%) \\
(\mathrm{pv})\end{array}$ \\
\hline $\begin{array}{l}\text { Dyspepsia/Abdominal } \\
\text { Pain }\end{array}$ & $\begin{array}{c}100 \\
0.165\end{array}$ & $\begin{array}{c}83.3 \\
0.794\end{array}$ & $\begin{array}{c}82.8 \\
0.592\end{array}$ & $\begin{array}{c}80.7 \\
0.812\end{array}$ & $\begin{array}{l}44.4 \\
0.009\end{array}$ & $\begin{array}{c}85.7 \\
0.279\end{array}$ & $\begin{array}{c}100 \\
0.369\end{array}$ & $\begin{array}{c}50 \\
0.309\end{array}$ & $\begin{array}{c}71.4 \\
0.612\end{array}$ \\
\hline Upper GI bleeding & $\begin{array}{c}28.6 \\
0.428\end{array}$ & $\begin{array}{c}16.7 \\
0.959\end{array}$ & $\begin{array}{c}20.7 \\
0.613\end{array}$ & $\begin{array}{c}12.9 \\
0.462\end{array}$ & $\begin{array}{l}55.6 \\
0.002\end{array}$ & $\begin{array}{c}11.4 \\
0.294\end{array}$ & $\begin{array}{c}33.3 \\
0.464\end{array}$ & $\begin{array}{c}0 \\
0.513\end{array}$ & $\begin{array}{c}14.3 \\
0.822\end{array}$ \\
\hline Vomiting & $\begin{array}{c}0 \\
0.356 \\
\end{array}$ & $\begin{array}{c}33.3 \\
0.063\end{array}$ & $\begin{array}{c}0 \\
0.043\end{array}$ & $\begin{array}{c}6.5 \\
0.42\end{array}$ & $\begin{array}{c}0 \\
0.292 \\
\end{array}$ & $\begin{array}{c}17.1 \\
0.148\end{array}$ & $\begin{array}{c}100 \\
0.000\end{array}$ & $\begin{array}{c}0 \\
0.627\end{array}$ & $\begin{array}{l}28.6 \\
0.110\end{array}$ \\
\hline Weight Loss & $\begin{array}{c}0 \\
0.404\end{array}$ & $\begin{array}{c}16.7 \\
0.483\end{array}$ & $\begin{array}{c}6.9 \\
0.703\end{array}$ & $\begin{array}{c}0 \\
0.057\end{array}$ & $\begin{array}{c}11.1 \\
0.794 \\
\end{array}$ & $\begin{array}{c}2.9 \\
0.168\end{array}$ & $\begin{array}{c}0 \\
0.589\end{array}$ & $\begin{array}{c}50 \\
0.037\end{array}$ & $\begin{array}{c}28.6 \\
0.057\end{array}$ \\
\hline Nausea & $\begin{array}{c}0 \\
0.526\end{array}$ & $\begin{array}{c}0 \\
0.558\end{array}$ & $\begin{array}{c}0 \\
0.165\end{array}$ & $\begin{array}{c}0 \\
0.148\end{array}$ & $\begin{array}{c}11.1 \\
0.416\end{array}$ & $\begin{array}{c}8.6 \\
0.320\end{array}$ & $\begin{array}{c}0 \\
0.681\end{array}$ & $\begin{array}{c}0 \\
0.738\end{array}$ & $\begin{array}{c}0 \\
0.526\end{array}$ \\
\hline Abdominal Swelling & $\begin{array}{c}0 \\
0.608\end{array}$ & $\begin{array}{c}0 \\
0.635\end{array}$ & $\begin{array}{c}3.4 \\
0.990\end{array}$ & $\begin{array}{c}0 \\
0.242\end{array}$ & $\begin{array}{c}0 \\
0.558\end{array}$ & $\begin{array}{c}0 \\
0.208\end{array}$ & $\begin{array}{c}0 \\
0.740\end{array}$ & $\begin{array}{c}0 \\
0.787\end{array}$ & $\begin{array}{c}14.3 \\
0.112\end{array}$ \\
\hline
\end{tabular}
$\mathrm{pv}-\mathrm{p}$ value.

We found dyspepsia (78.6\%) to be the commonest indication for $\mathrm{UGI}$ endoscopy referral which is in line with current knowledge worldwide [5, 12-18]. Malu et al also noticed dyspepsia (78.1\%) in their study at Zaria and so did Danbauchi et al, Aduful et al, Nkrumah et al, Khurram et al in Pakistan, Onyekwere et al in a tertiary hospital in Lagos and Cooper in Ohio, United States [12-18]. However Agbakwuru et al and Samaila et al in Katsina found peptic ulcer disease or its exacerbation as the commonest indication. This may be due to differences in the terminologies used by them $[11,19]$. This was distantly followed by upper gastrointestinal haemorrhage (17.4\%) and evaluation for persistent vomiting (10.5\%). UGI bleeding was also the second most common indication for UGI endoscopy in studies by Olokoba et al,Malu et al, Aduful et al, Khurram et $\mathrm{al}$, and Onyekwere et al, marginally coming third in the study by Agbakwuru et al., [10-12, 14, 16, 17]. Other common indications in our study are in the evaluation of patients for persistent vomiting, gastric cancer, gastro-oesophageal reflux disease and abdominal masses. These are also common indications in most studies world-wide [10-18]. Epigastric tenderness was the commonest physical finding, same as the finding by Danbauchi followed by right upper quadrant tenderness and then epigastric mass [13].

Table 5: Correlation between physical signs and endoscopic findings.

\begin{tabular}{|c|c|c|c|c|c|c|c|c|c|}
\hline Signs & $\begin{array}{c}\text { GERD } \\
(\%) \\
(p v)\end{array}$ & $\begin{array}{l}\text { Oesophagitis } \\
\qquad \begin{array}{c}\text { (\%) } \\
\text { (pv) }\end{array}\end{array}$ & $\begin{array}{c}\text { Gastritis } \\
\text { (\%) } \\
\text { (pv) }\end{array}$ & $\begin{array}{c}\text { Duodenitis } \\
\text { (\%) } \\
\text { (pv) }\end{array}$ & $\begin{array}{l}\text { Gastric } \\
\text { Ulcer } \\
(\%) \\
\text { (pv) }\end{array}$ & $\begin{array}{l}\text { Duodenal } \\
\text { Ulcer } \\
(\%) \\
(p v)\end{array}$ & $\begin{array}{c}\text { Pyloric } \\
\text { Stenosis } \\
(\%) \\
(\mathrm{pv})\end{array}$ & $\begin{array}{c}\text { Oesophageal } \\
\text { Cancer } \\
(\%) \\
\text { (pv) }\end{array}$ & $\begin{array}{c}\text { Gastric } \\
\text { Cancer } \\
(\%) \\
(\mathrm{pv})\end{array}$ \\
\hline $\begin{array}{l}\text { Epigastric } \\
\text { Tenderness }\end{array}$ & $\begin{array}{c}28.6 \\
0.869\end{array}$ & $\begin{array}{c}33.3 \\
0.917\end{array}$ & $\begin{array}{c}31.0 \\
0.963\end{array}$ & $\begin{array}{l}29.3 \\
0.754\end{array}$ & $\begin{array}{c}11.1 \\
0.178\end{array}$ & $\begin{array}{c}37.1 \\
0.412\end{array}$ & $\begin{array}{c}0 \\
0.237\end{array}$ & $\begin{array}{c}50 \\
0.569\end{array}$ & $\begin{array}{c}28.6 \\
0.869\end{array}$ \\
\hline Tenderness RUQ & $\begin{array}{c}0 \\
551\end{array}$ & $\begin{array}{c}0 \\
0.582\end{array}$ & $\begin{array}{c}3.4 \\
0.736\end{array}$ & $\begin{array}{c}3.2 \\
0.677\end{array}$ & $\begin{array}{c}0 \\
0.496\end{array}$ & $\begin{array}{c}8.6 \\
0.217\end{array}$ & $\begin{array}{c}0 \\
0.700\end{array}$ & $\begin{array}{c}0 \\
0.753\end{array}$ & $\begin{array}{c}0 \\
0.551\end{array}$ \\
\hline Murphy's sign & $\begin{array}{c}0 \\
0.770\end{array}$ & $\begin{array}{c}0 \\
0.787\end{array}$ & $\begin{array}{c}0 \\
0.522\end{array}$ & $\begin{array}{c}0 \\
0.505\end{array}$ & $\begin{array}{c}0 \\
0.738\end{array}$ & $\begin{array}{c}2.9 \\
0.295\end{array}$ & $\begin{array}{c}0 \\
0.850\end{array}$ & $\begin{array}{c}0 \\
0.877\end{array}$ & $\begin{array}{c}0 \\
0.770\end{array}$ \\
\hline Tenderness RIF & $\begin{array}{c}0 \\
0.719\end{array}$ & $\begin{array}{c}16.7 \\
0.004\end{array}$ & $\begin{array}{c}3.4 \\
0.442\end{array}$ & $\begin{array}{c}6.5 \\
0.027\end{array}$ & $\begin{array}{c}0 \\
0.681\end{array}$ & $\begin{array}{c}0 \\
0.377\end{array}$ & $\begin{array}{c}0 \\
0.816\end{array}$ & $\begin{array}{c}0 \\
0.850\end{array}$ & $\begin{array}{c}0 \\
0.719\end{array}$ \\
\hline Tenderness LIF & $\begin{array}{c}0 \\
0.836\end{array}$ & $\begin{array}{c}0 \\
0.849\end{array}$ & $\begin{array}{c}3.4 \\
0.026\end{array}$ & $\begin{array}{c}0 \\
0.638\end{array}$ & $\begin{array}{c}0 \\
0.814\end{array}$ & $\begin{array}{c}0 \\
0.612\end{array}$ & $\begin{array}{c}0 \\
0.894\end{array}$ & $\begin{array}{c}0 \\
0.913\end{array}$ & $\begin{array}{c}0 \\
0.836\end{array}$ \\
\hline Tenderness LUQ & $\begin{array}{c}0 \\
0.770\end{array}$ & $\begin{array}{l}16.7 \\
0.000\end{array}$ & $\begin{array}{c}0 \\
0.522\end{array}$ & $\begin{array}{c}0 \\
0.505\end{array}$ & $\begin{array}{c}0 \\
0.738\end{array}$ & $\begin{array}{c}0 \\
0.472\end{array}$ & $\begin{array}{c}0 \\
0.850\end{array}$ & $\begin{array}{c}0 \\
0.877\end{array}$ & $\begin{array}{c}0 \\
0.770\end{array}$ \\
\hline Epigastric Mass & $\begin{array}{c}0 \\
0.578\end{array}$ & $\begin{array}{c}0 \\
0.608\end{array}$ & $\begin{array}{c}6.9 \\
0.398\end{array}$ & $\begin{array}{c}3.2 \\
0.793\end{array}$ & $\begin{array}{c}0 \\
0.526\end{array}$ & $\begin{array}{c}0 \\
0.172\end{array}$ & $\begin{array}{c}0 \\
0.719\end{array}$ & $\begin{array}{c}0 \\
0.770\end{array}$ & $\begin{array}{l}28.6 \\
0.001\end{array}$ \\
\hline RIF Mass & $\begin{array}{c}0 \\
0.836\end{array}$ & $\begin{array}{c}16.7 \\
0.000\end{array}$ & $\begin{array}{c}0 \\
0.652\end{array}$ & $\begin{array}{c}3.2 \\
0.032\end{array}$ & $\begin{array}{c}0 \\
0.814\end{array}$ & $\begin{array}{c}0 \\
0.612\end{array}$ & $\begin{array}{c}0 \\
0.894\end{array}$ & $\begin{array}{c}0 \\
0.913\end{array}$ & $\begin{array}{c}0 \\
0.836\end{array}$ \\
\hline Hepatosplenomegaly & $\begin{array}{c}0 \\
0.640\end{array}$ & $\begin{array}{c}0 \\
0.666\end{array}$ & $\begin{array}{c}0 \\
0.307\end{array}$ & $\begin{array}{c}0 \\
0.287\end{array}$ & $\begin{array}{c}0 \\
0.594\end{array}$ & $\begin{array}{c}0 \\
0.251\end{array}$ & $\begin{array}{c}0 \\
0.762\end{array}$ & $\begin{array}{c}0 \\
0.806\end{array}$ & $\begin{array}{c}0 \\
0.640\end{array}$ \\
\hline
\end{tabular}
value.

Our UGI endoscopy study revealed abnormal findings in $66.3 \%$ of the patients. Malu in Northwestern Nigeria, Aduful in Ghana and Nkrumah in Saudi Arabia noted 67.3\%, 58.9\% and $66 \%$ respectively $[12,14,15]$. Some other investigators saw a much higher percentage of patients with abnormal endoscopic findings $[11,16]$. The relatively high normal endoscopy rate of $33.7 \%$ may be due to 
easy availability of the investigation in our centre and therefore a high referral rate. The commonest finding at endoscopy was duodenal ulcer occurring in 31\% of them. Malu and Nkrumah also observed duodenal ulcer as the commonest findings in their studies i. e. $26.6 \%$ and $75 \%$ respectively $[12,15]$ Other common findings were gastritis in $28 \%$ comparable to $35 \%$ obtained by Agbakwuru et al. at Ife,Nigeria and 31\% by Nkrumah in Saudi Arabia, duodenitis in $27 \%$ comparable to $24.8 \%$ by Malu at Zaria, Nigeria and $16 \%$ by Agbakwuru, gastric ulcer in $7.9 \%$ comparable to $9 \%$ by Agbakwuru and $9.3 \%$ by Jemilohun, gastrooesophageal reflux disease in $6 \%$ comparable to $8.1 \%$ by Jemilohun and gastric cancer in $6 \%$ comparable to $11.6 \%$ by Agbakwuru and are also common findings in other studies conducted in Nigeria, other parts of Africa and worldwide [11-13, $15,16,20]$.

In 30 patients with UGI bleeding gastric erosions and oesophageal varices were the leading causes with each accounting for $40 \%$ probably due to the apparent small number of the study; others being duodenal ulcer and gastric ulcer. These are also important causes of UGI bleeding elsewhere [12, 14, 21-23]. Mallory Weiss tear, though an important cause of UGI bleeding in Europe and America was not noted in our study and a rare finding in our environment because binge drinking is uncommon.

In tables 4 and 5, correlating clinical presentations with endoscopic findings: abdominal pain and gastric ulcer showed significant association ( $p$ value $<0.05$ ), as well as vomiting with pyloric stenosis and gastritis $(p<0.05)$ and weight loss with gastric cancer. In physical signs epigastric mass showed significant association with gastric cancer ( $p$ value $<0.05)$. These associations are consistent with studies worldwide $[24,25]$. In the patient with hepatosplenomegaly endocopy was normal and there were no varices found.

There was no significant statistical difference between the frequency of $\mathrm{H}$. pylori infection between those with endoscopic abnormality (62.5\%) and those with normal $(57 \%)$ findings $(p$ value $=0.056)$. This may be because of the small number of people tested for $\mathrm{H}$ pylori and that a control outside the hospital setting was not used. Association of $\mathrm{H}$. pylori infection with some of the abnormal endoscopic findings in our environment needs further collaborative studies involving larger number of patients.

The safety and acceptability of upper gastrointestinal endoscopy is well known. The commonest indication for UGI endoscopy in Lagos, Nigeria is dyspepsia. The commonest endoscopic abnormalities in Lagos, Nigeria are duodenal ulcer, gastritis and duodenitis. Further controlled studies are

needed with regards to all aspects of endoscopy in our environment. The provision and widespread availability of endoscopic service as an important factor in the management of upper gastrointestinal disease is evidence based and therefore strongly recommended.

\section{References}

1. Ament ME, Berquist WE, Vargas J, Perisic V. Fiberoptic upper intestinal endoscopy in infants and children. Pediatric Clinics of North America. 1988; 35(1): 141-55.

2. Heatley RV, Rathbone BJ. Dyspepsia: a dilemma for doctors? Lancet. 1987; 2(8562): 779-82.

3. Talley NJ, Weaver AL, Tesmer DL, Zinmeister AR. Lack of discriminant value of dyspepsia subgroups in patients referred for upper endoscopy. Gastroenterology. 1993; 105: 1378-86.

4. Colin-Jones DG. The management of dyspepsia Scandinavian Journal of Gastroenterology Supplement. 1988; 155: 96-100.

5. Axon AT, Bell GD, Jones RH, Quine MA, McCloy RF. Guidelines on appropriate indications for upper gastrointestinal endoscopy. Working Party of the Joint Committee of the Royal College of Physicians of London, Royal College of Surgeons of England, Royal College of Anaesthetists, Association of Surgeons, the British Society of Gastroenterology, and the Thoracic Society of Great Britain. BMJ. 1995; 310(6983): 8536.

6. Stabile BE, Smith BR, Weeks DL. Helicobacter pylori infection and surgical disease---part I. Current problems in surgery. 2005; 42(11): 756-89.

7. Goodwin S. Historical and microbiological perspectives. In: Northfield TC, Mendall M, Goggin PM, eds. Helicobacter pylori, epidemiology and management: Kluwer Academic Publishers, 1993:1-10

8. Akande B, Tai da Rocha-Afodu J. Observations on the presentation and management of peptic ulcer disease in Nigeria. Scandinavian Journal of Gastroenterology Supplement. 1986; 124: 1-8

9. Solanke TF. Upper gastrointestinal fibreendoscopy in Ibadan an analysis of 205 consecutive procedures. Ghana Med J. 1978; 17 : $95-7$.

10. Olokoba $A B$, Bojuwoye BJ. Indications for oesophagogastroduodenoscopy in Ilorin, Nigeria--a 30 month review. Nigerian Journal of Clinical Practice. 2010; 13(3): 2603.

11. Agbakwuru EA, Fatusi AO, Ndububa DA et al. Pattern and validity of clinical diagnosis of upper gastrointestinal diseases in south-west Nigeria. Afr Health Sci. 2006; 6(2): 98-103.

12. Malu AO, Wali SS, Kazmi R, Macauley D, Fakunle YM. Upper gastrointestinal endoscopy in Zaria, northern Nigeria. West African Journal of Medicine. 1990; 9(4): 279-84.

13. Danbauchi SS, Keshinro IB, Abdu-Gusau K. Fifteen years of upper gastrointestinal endoscopy in Zaria (1978 - 1993). African journal of medicine and medical sciences. 1999; 28(12): 87-90.

14. Aduful H, Naaeder S, Darko R, Baako B, Clegg-Lamptey J, Nkrumah $\mathrm{K}$, et al. Upper gastrointestinal endoscopy at the korle bu teaching hospital, accra, ghana. Ghana Med J. 2007; 41(1): 12-6

15. Nkrumah KN. Endoscopic evaluation of upper abdominal symptoms in adult patients, Saudi Aramco-Ai Hasa Health Center, Saudi Arabia. West African Journal of Medicine. 2002; 21(1): 1-4.

16. Khurram M, Khaar HT, Hasan Z, Umar M, Javed S, Asghar T, et al. A 12 years audit of upper gastrointestinal endoscopic procedures. Journal of the College of Physicians and Surgeons--Pakistan: JCPSP. 2003; 13(6): 321-4. 
17. Onyekwere CA, Hameed $\mathrm{H}$, Anomneze EE, Chibututu C. Upper gastrointestinal endoscopy findings in Nigerians: a review of 170 cases in Lagos. The Nigerian Postgraduate Medical Journal. 2008; 15(2): 126-9.

18. Cooper GS. Indications and contraindications for upper gastrointestinal endoscopy. Gastrointestinal Endoscopy Clinics of North America. 1994; 4(3): 439-54.

19. Samaila AA, Banye S, Buhari S, et al. Upper GI endoscopic findings in patients at General hospital, Katsina, Nigeria. Association for the study of the liver in Nigeria annual scientific conference. Jos. 2006:7.

20. Jemilohun AC, Otegbayo JA, Ola SO, Oluwasola OA, Akere A. Prevalence of Helicobacter pylori among Nigerian patients with dyspepsia in Ibadan. The Pan African Medical Journal. 2010; 6: 18.

21. Blatchford O, Davidson LA, Murray WR, Blatchford M, Pell J. Acute upper gastrointestinal haemorrhage in west of Scotland: case ascertainment study. BMJ. 1997; 315(7107): 510-4.

22. Dronfield MW, Langman MJ, Atkinson M, et al. Outcome of endoscopy and barium radiography for acute upper gastrointestinal bleeding: controlled trial in 1037 patients. $\mathrm{Br}$ Med J (Clin Res Ed). 1982; 284(6315): 545-8.

23. Peterson WL, Barnett CC, Smith HJ, Allen MH, Corbett DB. Routine early endoscopy in upper-gastrointestinal-tract bleeding: a randomized, controlled trial. The New England Journal of Medicine. 1981; 304(16): 925-9.

24. Mercer DW, Robinson EK. Stomach. In: Townsend CM, editor. Sabiston Textbook of Surgery. 17th ed. Philadelphia: Elsevier, 2004: 1265-322.

25. Dempsey DT. Stomach. In: Brunicardi FC, editor. Schwartz's Manual of Surgery. 8th ed. New York: McGraw-Hill companies, Inc., 2006:650-84. 